\title{
Housing of Pregnant Sows in Loose and Confined Systems - a Field Study. 2. Claw Lesions: Morphology, Prevalence, Location and Relation to Age
}

\author{
By H. Gjein ${ }^{l}$ and R. B. Larssen ${ }^{2}$
}

${ }^{1}$ Norwegian Pig Health Service, Central Veterinary Laboratory, and ${ }^{2}$ Department of Large Animal Clinical Sci-
ences, Norwegian College of Veterinary Medicine, Oslo, Norway.

Gjein H. and R.B. Larssen: Housing of pregnant sows in loose and confined systems - a field study. 2. Claw lesions: Morphology, prevalence, location and relation to age. Acta vet. scand. 1995, 36, 433-442. - A field study of 36 Norwegian sow herds was conducted over a 12 month period, 18 herds had loose housing of pregnant sows and 18 herds had confined (stalled or tethered) dry sows. Fifteen of the loose housing herds had partly slatted concrete floors while 3 herds had other kinds of flooring. The types of claw lesions that were observed in these herds are described. The most prevalent lesions on both loose sows and confined sows were side wall cracks, heel lesions, cracks in the white line and overgrown heels. The lateral hind claws were the most frequent location for lesions and they were more severe than at other sites. These lesions tended to show a bilateral occurrence. More than $96 \%$ of slaughtered loose sows and $80 \%$ of slaughtered confined sows had at least 1 lesion on the lateral hind claws. The prevalence of claw lesions showed no obvious age pattern. However the prevalence seemed to be lower for the first litter sows and increased slightly thereafter, especially in the confined herds.

swine; toe injuries; slatted floors; electronic feeding; epidemiology.

\section{Introduction}

Claw lesions are frequently found on sows and fatteners, however, the clinical significance of these lesions is most important in sows (Penny et al. 1963, Erdal \& Grøndalen 1987). Claw lesions in pigs are a result of the floor quality, nutrition, heredity and management. Slatted or partly slatted concrete floors predispose for claw lesions (Fritchen 1979). Several studies have shown that the vitamin biotin is essential for normal claw health and that a lack of biotin leads to claw lesions (Brooks 1982, Bryant et al 1985, Kornegay 1986, Misir \& Blair 1986, Simmins \& Brooks 1988).

More claw lesions are found on the lateral claws than on the medial claws. The unequal weight distribution that occurs with more of the pig's weight on the outer claws than on the inner claws would explain this observation ( $\mathrm{Ka}$ man et al. 1987). Kornegay et al. (1990) showed that as the difference in size between the outer and inner claws increased, the frequency of outer claws with lesions increased and the frequency of inner claws with lesions decreased. These authors also showed that the frequency of sows with claw lesions increased with age.

The most common types of claw lesions are lesions in the heel, cracks in the junction between the heel and the toe, cracks in the white line and cracks in the wall (Brooks et al. 1977, Simmins \& Brooks 1988, Kornegay et al. 1990).

The present study was a part of a larger field study that was undertaken to evaluate the health 
and welfare of pregnant sows in loose and confined housing systems. This paper describes the types of claw lesions, their location, frequency and severity. The relationship of lesions to age of sows and the interrelationship between different types of lesions are also described.

\section{Materials and methods \\ Design}

The study was a prospective multiple cross sectional study of 2 open cohorts.

The loose cohort consisted of 18 herds and was a random sample from all herds with loose housing of pregnant sows within $150 \mathrm{~km}$ from Oslo. Two of the loose herds originally included in the study were kept separate during analysis of claw lesions, because they had deep litter flooring. One further loose herd was excluded after 7 months observation, because the herd changed from partly slatted concrete floor to deep litter. Fifteen herds had partly slatted concrete floors and electronic sow feeding. The average number of sow-years in these 15 herds was 39.2 (26-70), and the group size of pregnant loose sows was between 15 and 40 . One sow-year is the equivalent of a sow older than 6 months that spend a complete year in the herd, however only sows that subsequently farrow are included.

The confined cohort consisted of 18 herds and was a random sample from all herds with confined pregnant sows (neck grides or individual crates) in the same region. Average herd size was 30.1 sows-year (17-53).

Further details of design, management and selection of herds are presented elsewhere (Gjein \& Larssen 1995 a,b).

\section{Claw examinations}

The hind feet of all sows were examined in the herds 3 times (Oct.'89, Apr.'90 and Oct. 90). The claws were brushed and if necessary washed before the clinical examination. Over a period of 10 months both the front and the hind claws were collected from sows that were slaughtered in these herds. These claws were subsequently examined in more detail at the laboratory. Claws were collected only from about one half of the culled sows because of practical problems in the abattoir. There was no systematic selection of sows, thus the examined sows were likely to be representative for all the culled sows. All examinations - both clinical and post mortem - were performed by the same person. The categorization were a minor modification of the method described by Brooks et al. (1977). On both claws of each foot, 6 different types of claw lesions were evaluated (Fig. 1):

a) Side wall lesions: All cracks in the wall, both horizontal and vertical.

b) Heel lesions: Cracks in the soft heel of the claw, erosions and bruisings.

c) Overgrown heel: Excessive growth of the heel tissue.

d) Cracks in the white line: White line lesions, most frequently at the abaxial perimeter of the claw.

e) Cracks in the junction of the heel and toe: Cracks in the tissue where the heel and toe meet (nearly all sows had a small cleft at this junction, but only pathological cracks were scored).

f) Toe cracks: Cracks in the harder toe horn, between the heel and the axial and abaxial white line.

Claw lesions (a,b,c,d,e,f) were scored from 1 to 5 . The scoring was a subjective characterization of the severity of the lesion. Important factors in the scoring were the extent and depth of the lesion and secondary changes resulting from the claw lesion.

Score 1: Normal claw.

Score 2: Small, superficial cracks or lesions in the epidermis.

Score 3: More serious lesions that were con- 

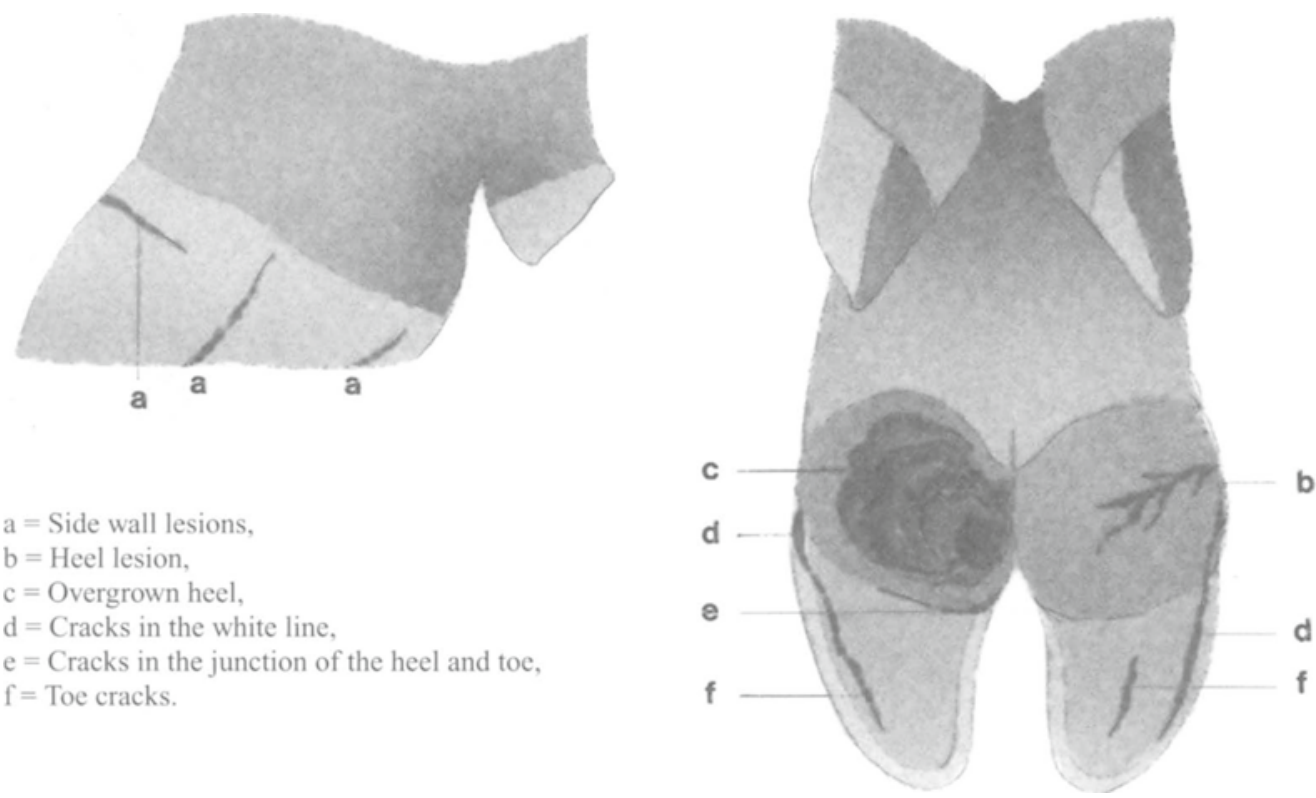

$\mathrm{a}=$ Side wall lesions,

$\mathrm{b}=$ Heel lesion,

$\mathrm{c}=$ Overgrown heel,

$\mathrm{d}=$ Cracks in the white line,

$\mathrm{e}=$ Cracks in the junction of the heel and toe,

$\mathrm{f}=$ Toe cracks.

Figure 1. Types and location of claw lesions (modified after Brooks et al. 1977).

fined to the epidermis.

Score 4: Serious, deep lesions that extended into the corium.

Score 5: Very serious and deep cracks that extended into the corium or subcutis.

Scoring of overgrown heel (c) was a subjective classification of the overgrowth. Score 1 was a normal claw and score 5 was a claw with a very severe overgrowth.

Claw lesions with score 3,4 and 5 were classified as major lesions.

For each of the 6 types of claw lesions, the prevalence proportion within each herd was calculated. The loose and confined cohorts were then compared using the mean of these prevalences for each cohort (Gjein \& Larssen 1995 b). The severity of each type of lesion in the herds was evaluated by calculating the mean score among the injured claws, i.e. claws with score $\geq 2$ for that type of lesion.

Information on farrowing date and number of litters (age) was obtained from the Norwegian sow recording scheme.

\section{Statistical methods}

The sow observations used in this paper were 3 repeated examinations of the same variables. Thus dependency existed both between the examinations within animals and between the animals within a herd. This was taken into account during the analysis. The data are presented and analysed using either sow observation, claw, animal or herd as the unit of concern depending on the question to be answered. Unless otherwise stated the measure of disease on herd level is the arithmetic mean of the prevalence proportions of sows with the lesion at the 4 examinations.

The Statistical Analysis System (Institute Inc. 1989) was used for data processing and statistical analysis. Students t-test was used to compare the prevalence of each type of lesion 
Table 1. The mean prevalence proportion of the 6 different types of claw lesions on hind feet in loose and confined herds at the 4 examinations. The mean score of the different claw lesions at the 3 clinical examinations. The correlations coefficients between left and right lateral hind claws for the same type of lesions in the Oct.' 89 examination.

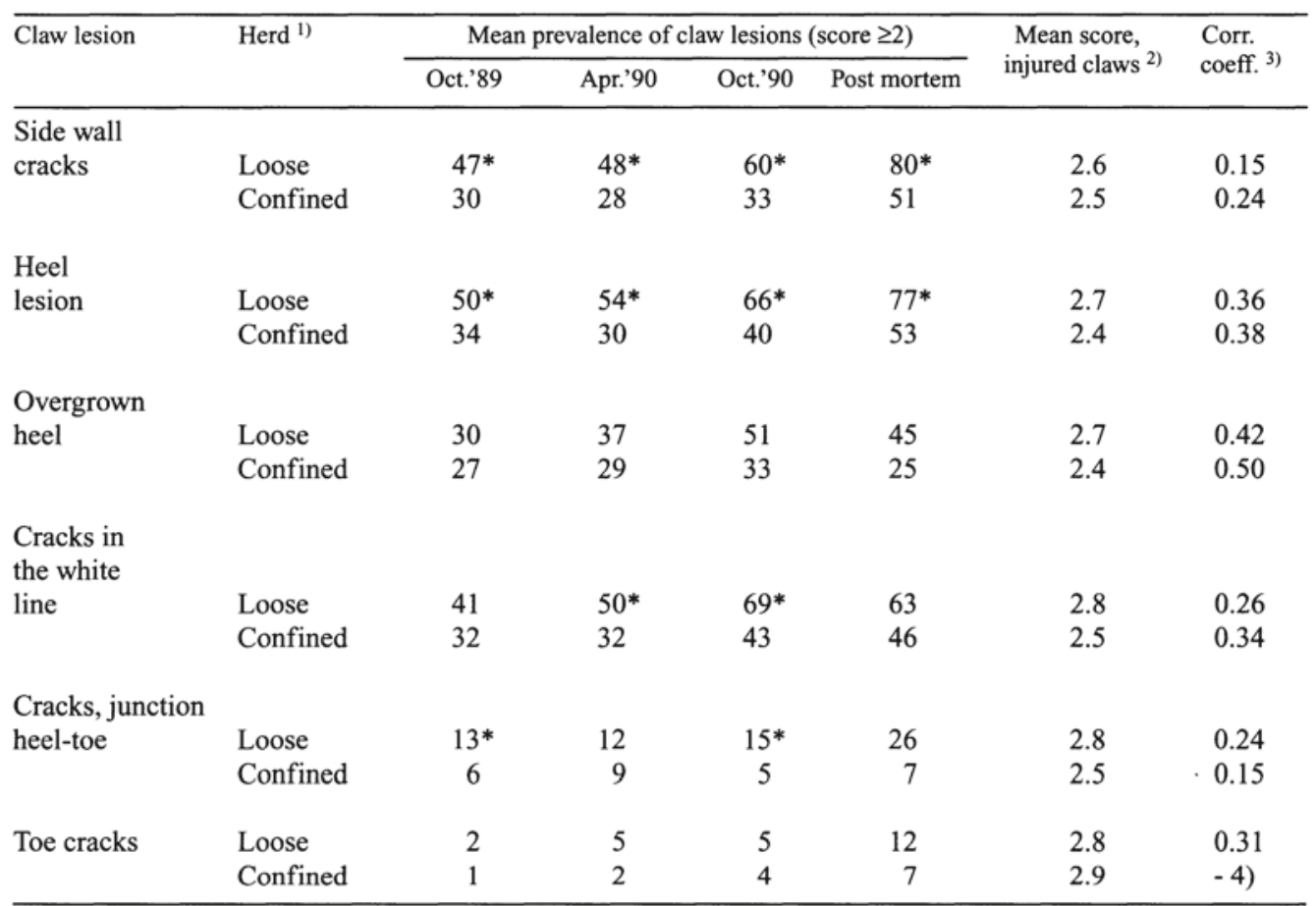

1) $\mathrm{n}$, loose herds $=16$ (Oct.'89, Apr.'90, Post mortem) or 15 (Oct.'90). $\mathrm{n}$, confined herds $=18$.

2) $\mathrm{n}$, loose sow observations $=1436$ and $\mathrm{n}$, confined sow observations $=1260$

3) The Spearman's rank correlation coefficients $(p<0.0001) n$, loose sows $=499$ and $n$, confined sows $=452$

4) Not computed due to few lesions

* Significant difference between loose and confined herds $(\mathrm{p}<0.05)$.

Table 2. Prevalence proportion of claw lesions and mean score of injured claws in the post mortem examination.

(For loose herds $\mathrm{n}=16$ and for confined herds $\mathrm{n}=18$ ).

\begin{tabular}{|c|c|c|c|c|c|c|c|c|c|}
\hline & \multirow{3}{*}{$\begin{array}{l}\text { No of } \\
\text { sows }\end{array}$} & \multicolumn{4}{|c|}{ Front } & \multicolumn{4}{|c|}{ Hind } \\
\hline & & \multicolumn{2}{|c|}{ Medial } & \multicolumn{2}{|c|}{ Lateral } & \multicolumn{2}{|c|}{ Medial } & \multicolumn{2}{|c|}{ Lateral } \\
\hline & & $\%$ & $\begin{array}{l}\text { Mean } \\
\text { score }\end{array}$ & $\%$ & $\begin{array}{l}\text { Mean } \\
\text { score }\end{array}$ & $\%$ & $\begin{array}{l}\text { Mean } \\
\text { score }\end{array}$ & $\%$ & $\begin{array}{l}\text { Mean } \\
\text { score }\end{array}$ \\
\hline Loose & 116 & $37.9 \mathrm{a}$ & 2.4 & $76.5 \mathrm{a}, \mathrm{b}$ & 2.6 & $35.1 \mathrm{c}$ & 2.6 & 96.5 b,c & 2.9 \\
\hline Confined & 109 & $25.7 \mathrm{~d}$ & 2.3 & $49.5 \mathrm{~d}, \mathrm{e}$ & 2.5 & $26.6 \mathrm{f}$ & 2.7 & $80.7 \mathrm{e}, \mathrm{f}$ & 2.6 \\
\hline
\end{tabular}

a,b,c,d,e,f Prevalences marked with the same letter were all significantly different $(\mathrm{p}<0.001)$. 


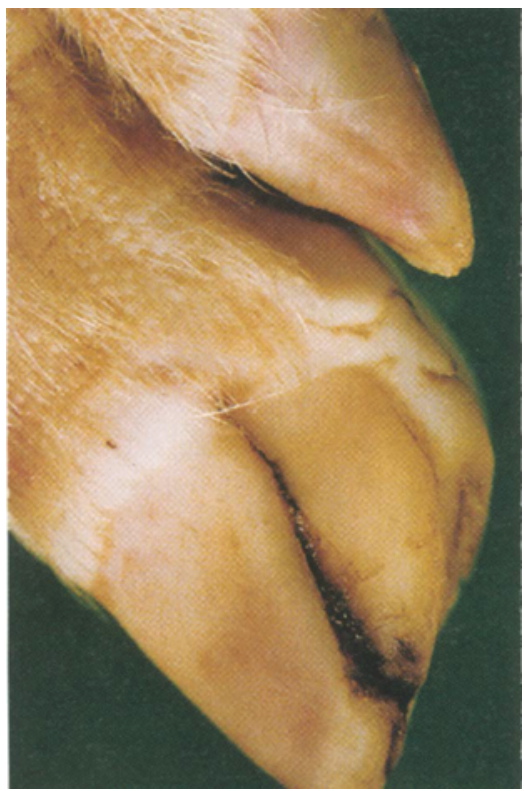

Figure 2. Side wall crack. A typical vertical side wall crack, this crack got score 4 .

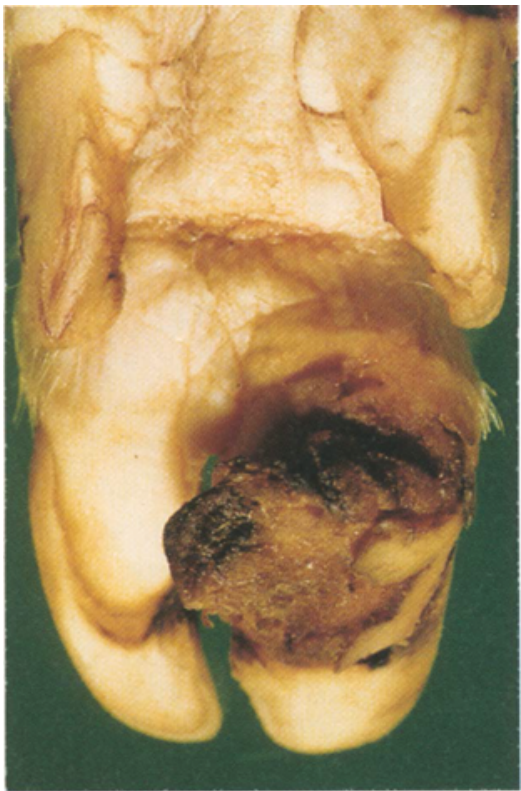

Figure 4. Overgrown heel (score 4).

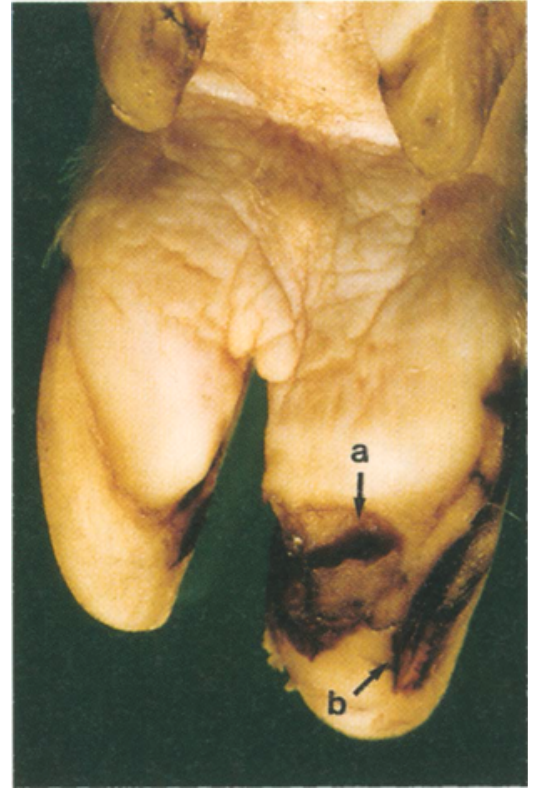

Figure 3. Crack in the heel (a) score 4, and in the toe (b) score 5 .

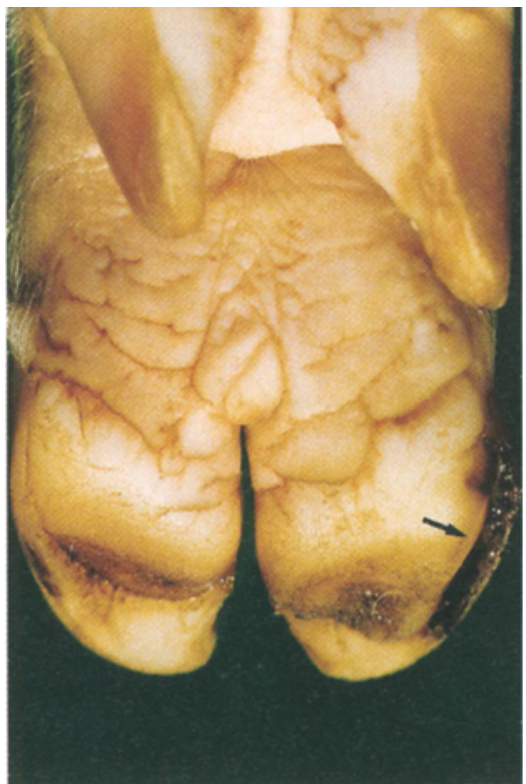

Figure 5. Crack in the white line (score 5). 


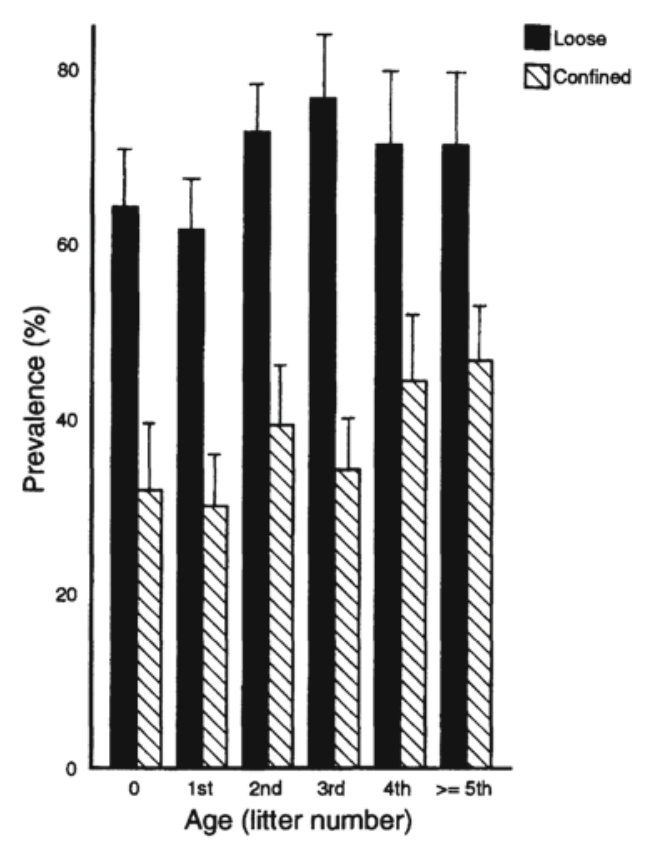

Figure 6. Mean prevalence proportion (with $95 \%$ $\mathrm{CI}$ ) of sows with major claw lesions in relation to age (number of litters), loose and confined sows (loose sow observations: $n=1436$, confined sow observations: $\mathrm{n}=1260$ ).

between loose and confined herds at each registration (Table 1). Spearman's rank correlation based on lesion scores in examination 1 was calculated both to show correlations between different lesions on the same claw i.e. using claw as the unit; and to show correlations between anatomical localisation for each type of claw lesion i.e. using animal as the unit (Table 1). These correlations were all calculated separately for each cohort (loose and confined) and only on data from the clinical examination in October 1989.

Wilcoxon's sign test was used to test differences in occurrence of claw-lesions between anatomical localisations i.e. using animal as unit (Table 2). These sign tests were all computed separately for each cohort and only on data from the post mortem examination. Also $95 \%$ confidence intervals $(\mathrm{CI})$ for mean prevalence proportion of sows with major claw lesions in relation to age were calculated using sow observation as unit (Fig. 6).

\section{Results \\ Prevalence Proportions and severity of claw le- sions}

The mean prevalence proportion of the different types of claw lesions in the loose and confined herds is presented in Table 1. All lesions seemed more prevalent in loose than in confined herds at all 4 examinations (clinical and post mortem), and except for toe cracks, the mean scores for the injured claws were also higher among sows in the loose herds.

Side wall cracks (Fig. 2) were found in about half of the loose sows and in about a third of the confined sows at the clinical examinations. At the post mortem examination the mean prevalence proportion was $80 \%$ in the loose herds and $51 \%$ in the confined herds. The side wall cracks were most frequent in the posterior part of the abaxial side wall where the wall tissue meets the heel tissue, and just in front of this point. Cracks in the medial wall of the claw were rare both in the lateral and medial claws. The vertical cracks were more prevalent than the horizontal cracks. The most serious lesions in the side wall (score $=4$ or 5) often extended from the lower edge up to the coronary band.

Heel lesions (Fig. 3) were found in about half of the loose sows and in a third of the confined sows at the clinical examinations $(77 \%$ and $53 \%$ in the post mortem examination). The heel lesions were dominated by cracks, whereas erosions were less frequent. The deep cracks $(1-2 \mathrm{~cm})$ were painful and the sows were lame, especially when the cracks were complicated with infections. 
Cracks in the white line were found in about half of the loose sows and in a third of the confined sows at the clinical examinations. These cracks could extend all around the claw, but were more frequent on the abaxial part of the claw than of the toe and axial parts of the claw (Fig. 5). The cracks could be long $(2-4 \mathrm{~cm})$ and deep $(0.5-2 \mathrm{~cm})$.

Cracks in the junction between the heel and the toe. Nearly all sows in this study had a small cleft between the heel and the sole tissue. This was considered to be normal. The mean prevalence proportion of cracks in loose herds varied from 12 to $26 \%$ and in confined herds from 5 to $9 \%$.

Cracks in the toe (Fig. 3). These cracks, when present, were often a part of a crack in the white line, however they were seldom seen. The mean prevalence proportion in loose herds varied from 2 to $5 \%$ and in confined herds from 1 to $4 \%$ at the clinical examinations. The severity of the lesions was high, with a mean score of 2.8 in loose and 2.9 in confined sows.

Overgrown heel. Excessive growth of the soft heel tissue (Fig. 4), was found in about 40 $\%$ of the loose sows and $30 \%$ of the confined sows at the clinical and post mortem examination. Overgrowth of the heels was more severe among the loose sows than among the confined sows. Overgrown heel was most frequently observed on the lateral hind claws and often observed on both the hind feet at the same time (Table 1). These lesions were mostly seen in herds with wet floors.

\section{The location of claw lesions}

More lesions were found on the lateral claws than on the medial claws (Table 2). For both the loose and the confined sows, the prevalence of lesions on the lateral front claws was twice as high as the prevalence on the medial front claws $(\mathrm{p}<0.001)$. In the hind feet, there were about 3 times more lesions on the lateral claws than on the medial claws $(\mathrm{p}<0.001)$. For both loose and confined sows, lateral hind claws had more lesions than lateral front claws $(\mathrm{p}<0.001)$, while no difference was found in the prevalence between the medial hind and medial front claws.

There were small differences in the severity of the lesions on the different claws. The mean score of the lesions on the lateral hind claws of the loose sows was slightly higher than on the other claws, whereas the score of the medial front claws tended to be lower than on the other claws.

\section{Correlations between claw lesions}

The correlation coefficients between the different lesions on the same claw were calculated. The highest correlation coefficient was between overgrowth and lesions in the heel, it was between 0.38 and $0.70(p<0.0001)$ for the different claws in loose and confined herds. The highest correlation between these 2 lesions occurred on the lateral claws.

The same type of claw lesions tended to show a bilateral occurrence on the legs, especially overgrown heels. This tendency of bilaterally occurrence was most evident on the lateral hind claws (Table 1).

\section{Age and claw lesions}

There was no obvious age pattern, however the prevalence of claw lesions showed a slight tendency to increase with age (Fig. 6), especially in the confined herds. In loose herds, the prevalence proportion of sows with major claw lesions (score $\geq 3$ ) increased from $62 \%$ in first litter sows to $77 \%$ in third litter sows. The prevalence proportion subsequently decreased to $71 \%$ in older sows. In the confined herds, the prevalence proportion of major claw lesions increased from $30 \%$ in the first litter sows to $47 \%$ in the older sows. The average age (number of litters) of the sows that were examined at the 3 
clinical examinations increased from 1.7 litters at the first examination to 2.3 litters at the third examination in the loose herds. In the confined herds the average age increased from 2.2 to 2.5 litters from the first to the third examination.

\section{Discussion}

The prevalence proportion of sows with claw lesions was found to be high both in loose housed and confined sows. More than $96 \%$ of slaughtered loose sows on partly slatted floors and $80 \%$ of slaughtered confined sows had at least one lesion on the lateral hind claws. The other claws also showed a high prevalence of lesions. The most frequent types of lesions in both housing systems were side wall cracks, lesions in the heel, cracks in the white line and overgrowth of the heel.

A similar high prevalence of these lesions has been observed in other studies (Penny et al. 1963, Brooks et al. 1977, Simmins \& Brooks 1988, Kornegay et al. 1990) although de Koning et al. (1990) also reported a high prevalence of lesions in the junction of the heel and toe.

The cracks of the side wall were often observed to be vertical on the abaxial and axial part of the wall, and these lesions may have been caused when the claws were injured in the slot between the slats. Horizontal cracks were seldom seen and were predominately in the dorsal part of the wall. Brooks et al. (1977) suggested that lesions in the side wall of the claw originated from damage occurring in the coronary band. Disruption of normal horn development at the coronet is followed by lesions in the wall.

Lesions and overgrowth of the heel were often seen on the same claw. There was a strong correlation between these 2 lesions and they were also often found bilaterally. The overgrowth of the heel seemed to be more common in herds with bad floor hygiene, i.e. wet floors with a lot of urine and faeces. This suggests that environmental factors (quality of floor, wetness, clean- liness) may play a major role for the development of these lesions.

The overgrowth of the heel may be regarded as a chronic reaction caused by bad floors or as a repair process after an acute lesion. The overgrown heel consists of granulation tissue that is more suspectible to injuries than normal heel. In addition, the heel of the normal claw consists of soft tissue and is the part of the claw that bears most weight and therefore is prone to lesions. Concrete floors, both solid and partially slatted, are considered to be a major factor contributing to claw lesions (Kornegay et al. 1990). The white line cracks were often severe and localized to the posterior and abaxial part of the claw. This type of crack may also be a result of the quality of the floor and the environment. The cracks in the abaxial wall and the white line were often seen on the same claw. Similar observations were also reported by Brooks et al. 1977 and Simmins \& Brooks (1988).

The low prevalence proportion of lesions in the toe and between the heel and toe found in the present study differs from the high prevalence observed by de Koning et al. (1990).

The lateral hind claws were the most frequent location for lesions. This is in accordance with several other studies which have shown that claw lesions are most prevalent on the lateral hind claws (Penny et al. 1963, Brooks et al. 1977, Arthur et al. 1983, Webb et al. 1984, Kornegay et al. 1990). The difference in prevalence proportion of claw lesions between lateral and medial claws can be explained by the inequality in size of the digits. The lateral claws take more of the pig's weight than the medial claws (Penny et al. 1963). The front claws are more uniform in size than the claws on the hind legs (Penny et al. 1963, Kaman et al. 1987). Accordingly, the difference in the prevalence proportion of lesions is not so evident with the front claws as with the hind claws (Simmins \& Brooks 1988). Kornegay et al. (1990) reported that the number 
of lesions on a leg became larger as the difference in size between the medial and lateral claws increased.

There tended to be a greater difference in prevalence proportion of claw lesions between lateral front and hind feet in the confined herds than in the loose herds. The explanation may be the better environment of the front claws in stalls and boxes, than of the hind claws. The confined sows stood with their hind legs either on a concrete floor which was often wet, or on concrete slats. The front legs of the confined sows were on a dry concrete floor. However, in the loose herds the front and hind legs of the sows experienced the same conditions. Wet, rough or slatted concrete floors give more claw lesions than dry floors (Penny et al. 1965).

The prevalence proportion of sows with major claw lesions (score $\geq 3$ ) tended to increase more with age in the confined herds than in the loose herds. This may be explained by the lower culling rate in the confined herds (Gjein \& Larssen 1994 a). Sows with claw lesions are more able to "survive" in a confined herd than in a loose herd. The culling of sows with foot and leg problems will hide the age effect of foot and leg diseases. Thus, the real age effect is probably more pronounced than shown in this study. The long term effect of concrete floors and the increasing weight of sows with age are factors that can explain the age effect on claw health.

\section{Conclusions}

This study shows that nearly all loose sows on partly slatted floors have claw lesions. Side wall cracks and heel lesions were the types of lesions most often found in both housing systems, however the prevalence proportion of these 2 lesions was significantly higher in the loose herds than in the confined herds. The lateral hind claws were most prone to injuries.

\section{Acknowledgements}

We thank Nina Lunderød for excellent technical assistance and the personal at the local slaughterhouses for collecting claws from sows.

\section{References}

Arthur SR, Kornegay ET, Thomas HR, Veit HP, Notter $D R$, Barczewski RA: Restricted energy intake and elevated calcium and phosphorus intake for gilts during growth. III. Characterization of feet and limbs and soundness scores of sows during three parities. J. Anim. Sci. 1983, 56, 876-886.

Brooks $\mathrm{PH}$ : Biotin in pig nutrition. Pig News Inf. 1982, 3, 29-32.

Brooks PH, Smith DA, Irwin VCR: Biotin-supplementation of diets; the incidence of foot lesions, and the reproductive performance of sows. Vet. Rec. 1977, 101, 46-50.

Bryant KL, Kornegay ET, Knight JW, Veit HP, Notter $D R$ : Supplemental biotin for swine. III.Influence of supplementation to corn- and wheat-based diets on the incidence and severity of toe lesions, hair and skin characteristics and structural soundness of sows housed in confinement during four parities. J. Anim. Sci. 1985, 60, 154-162.

de Koning R, Backus GBC, Vermeer HM: Welfare, behaviour, and performance; partly slatted systems. Electronic identification in pig production; an international symposium exchanging experience between countries. Stoneleigh, 1990, 53-62.

Erdal DE, Grøndalen T: Klauvlidelser hos gris, registrert og bedømt etter slakting; en preliminær rapport. Nord. Jordbr. Forsk. 1987, 69, p. 614.

Fritschen RD: Housing and its effect on feet and leg problems. Proc. pig vet. Soc. 1979, 5, 95-98.

Gjein $H$, Larssen RB: Housing of pregnant sows in loose and confined systems - a field study. 1. Vulva and body lesions, culling reasons and production results. Acta vet. scand. 1995a, 36, 185200.

Gjein H, Larssen RB: Housing of pregnant sows in loose and confined systems - a field study. 3 . The impact of housing factors on claw lesions. Acta vet. scand. 1995b, 36, 443-450.

Kaman J, Pivnik L, Henys I, Kanka P, Veverka V: Syndrome of the asymmetry of digits and the frequency of its occurrence in slaughter pigs. Acta vet. Brno, 1987, 56, 427-448.

Kornegay ET: Biotin in swine production; a review. Livest. Prod. Sci. 1986, 14, 65-69. 
Kornegay ET, Bryant KL, Notter DR: Toe lesion development in gilts and sows housed in confinement as influenced by toe size and toe location. Appl. agr. Res. 1990, 5, 327-334.

Misir R, Blair R: Effect of biotin supplementation of a barley-wheat diet on restoration of healthy feet, legs and skin of biotin deficient sows. Res. vet. Sci. 1986, 40, 212-218.

Penny RHC, Osborne AD, Wright AI: The causes and incidence of lameness in store and adult pigs. Vet. Rec. 1963, 75, 1225-1240.

Penny RHC, Osborne AD, Wright AI, Stephens TK: Foot-rot in pigs; observations on the clinical disease. Vet. Rec. 1965, 77, 1101-1108.

SAS Inst. Inc.: Ver. 6.04 for DOS. Cary, NC, 1989.

Simmins PH, Brooks PH: Supplementary biotin for sows; effect on claw integrity. Vet. Rec. 1988, 122, 431-435.

Webb NG, Penny RHC, Johnston AM: Effect of a dietary supplement of biotin on pig hoof horn strength and hardness. Vet. Rec. 1984, 114, 185189.

\begin{abstract}
Sammendrag
Løsgående og fikserte gjeldpurker - en feltstudie av helse og velferd. 2. Klauvskader: Morfologi, prevalens, lokalisasjon og forhold til alder.
\end{abstract}

En feltstudie av 36 purkebesetninger ble gjennomført i løpet av 12 måneder. 18 besetninger hadde løsgående gjeldpurker, mens 18 besetninger hadde fikserte eller oppbundne purker.

De 4 typer klauvskader med høyest prevalens i alle typer besetninger var : skader i balleputen, skader $\mathrm{i}$ sideveggen, sprekker i den hvite linje og forvokst ballepute. Disse 4 typer klauvskader forekom ofte bilateralt på de ytre bakklauvene.

Det var høyest frekvens og høyest score på skadene på de ytre bakklauver. Mer enn $96 \%$ av de løsgående purker på betongspaltegulv og $80 \%$ av de fikserte purkene som ble slaktet hadde klauvskade på de laterale bakklauvene.

Det var en svak tendens til økende prevalens av purker med klauvskader med økende alder.

(Received June 1, 1994; accepted June 16, 1995).

Reprints may be obtained from: H. Gjein, Central Veterinary Laboratory, P.O. Box 8156, Dep., N-0033 Oslo, Norway. 